\title{
Reviewing Hate Speech in Indonesian Social Media Content: Gender and Discourse Perspectives
}

\author{
Sri Wahyuningsih \\ Institut Agama Islam Negeri Kudus, Central Java. Indonesia \\ email: wahyuningsih@iainkudus.ac.id
}

\begin{abstract}
:
The increased conflicts and online propaganda on social media recently have raised the negative impacts on the society such as violence and conflicts. This article mainly reviews the hate speech in Indonesian social media content viewed from the gender and discourse perspectives. Further, it explores the importance of using the language of peace on social media such as you tube, Twitter, Facebook, Instagram and so on as an effort to prevent the potential for conflicts. This study uses a descriptive qualitative method to describe the phenomenon of the use of hate speech and propaganda in social media. The writer collected data from a number of quotes and writing on social media particularly Facebook and Instagram containing hate speech, threats, propaganda, and incitement leading to negative reactions of the society. The result shows that women may have more preference dealing with physical appearance issues to political ones. This can be seen clearly through the comments stated by women in social media particularly Facebook. Meanwhile, men tend to have preferences on commenting political issues in social media to physical appearance. Furthermore, they dare to take a risk and power in relation with political issues. Thus, the users of social media both men and women are encouraged to be wise in using social media that can be achieved by using the language of peace to prevent the potential for online conflicts among the society.
\end{abstract}

Keywords: Gender, Hate Speech, Social Media

\section{INTRODUCTION}

In recent years, the increased presence of hate speech, propaganda, insults and verbal violence on social media has raised the conflicts among a large group of people. In this matter, conflicts have become a main concern for some countries. There are a number of factors influencing the conflicts. Those include discrimination, political aspect, marginalization and so forth. Regarding this, building a peace requires efforts including active investments, good leaderships, a better productive media world and settled educational values. In order to achieve that, moral is fundamentally needed to create respects ELT-Lectura, Vol 8, No 1, February 2021 that will lead to a peace. As a matter of fact, recently there has been a phenomenon of language on social media accomplished by pictures, yelling, and screaming that will lead to chaos, verbal and physical violence. Indeed, utterances or statements rapidly spread out through social media having main roles to convey the message and communication. In this matter, social media have dramatically altered people's communication and their relationships.

In addition, social media is violent since it is a means of discourse and discourse is mainly related to another type of violence, the symbolic violence (Recuero, 2015). In spite of the benefits, social media has been 
viewed to give a negative impact according to some in that it has been utilized to convey disorders, conflicts and violence, for instance riots in Greece and England (Niekerk, 2013). In accordance with it, although platforms of social media including Facebook, Twitter and Instagram can enhance partners in building a better communication, there are other aspects of these that can be used to do psychological abuse (Stephenson, Wickham, \& Capezza, 2018). In addition, social media can be a medium to spread harassment, stalking, and sexual victimization both in online and offline situations (Kennedy \& Taylor, 2010). Regarding this, the users of social media both men and women have responsibility to be wise in choosing the words and using acts of discourse in order to prevent the potential for conflicts and violence.

This paper mainly investigates the hate speech and some exemplary pictures, meme and writing on social media such as Facebook and Instagram viewed from gender and discourse perspectives.

\section{METHOD}

This study anchors in a descriptive qualitative method. It deals with the descriptions of the role of using language of peace on social media considering the negative impacts of social media including conflicts and violence due to the hate speech, hoax news, meme and so on. Data were taken from some examples of quotes or writing and meme on social media particularly Facebook and Instagram. The data then were reviewed systematically based on the gender and discourse perspectives.

\section{FINDINGS AND DISCUSSION Reviewing Hate Speech in Indonesian Social Media Content}

Social network is generally connected to the society with different communication rules. Networks in the same spaces could be from family, work and colleagues. With regard to this, it is considerably not easy for social media users to select an appropriate tone to a large group of people. In face-to-face communication, we may find the feedback signals that give information to others when they are in an uncomfortable and dangerous topic during the communication so that people may switch the topic and mend the communication. Unfortunately, this information does not appear in online social media. Indeed, the users of social media are talking with a screen not a person. As a result, what is stated or written to some people may give the negative reactions violently due to the context collapse. The following meme and quotes on social media contain hate speech, propaganda and insult that will lead to conflicts from the audience:

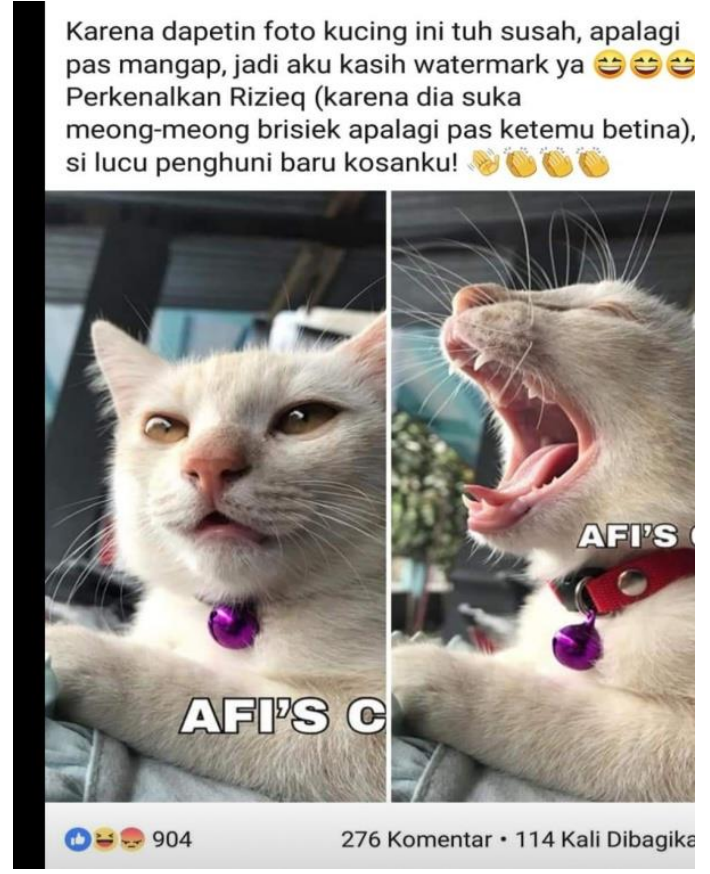

Karena dapetin foto kucing ini tuh susah, apalagi

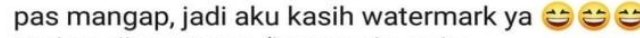
Perkenalkan Rizieq (karena dia suka

meong-meong brisiek apalagi pas ketemu betina), si lucu penghuni baru kosanku! 
Figure 1. Meme from Facebook published by the female students in one of Universities in Indonesia. The message reads, " Since it's difficult to find an amazing picture of cat, I call it as Rizieq who likes saying "meow" particularly when meeting female ones".

The meme above denotes the offensive content or hate speech to a particular person, Habib Riziq Shihab, the founder of Front Pembela Islam (FPI). In addition, the above meme indicates the verbal violence intended to Habib Riziq that is assumed as an animal, cat. It is proved by the use of some words related to animal such as 'Meong-Meong', 'Betina', 'Cat'. Regarding this, the female language users above are less competent in using language and she does not aware of pragmatics that will lead to chaos, verbal violence and conflicts from the audience. It can be seen from a number of comments in the meme, 276 comments from the audience and it has been shared by others 114 times. Furthermore, the lack of fundamental legal prohibitions against hate speech in Indonesia may lead people to share meme and information containing hate speech and propaganda. Furthermore, hate speech may refer to fighting words and incitement and it can be illegal if it rises to the level of true threats (Carlson, 2018).

Thus, the description of memes above proves that using language of peace is crucial to prevent the context collapse and conflicts from audience. Furthermore, hate speech can be a key role in hindering social peace. Therefore, we should be responsible for words and speech that we uttered. Besides, the following meme captured in
Facebook also denotes the hate speech.

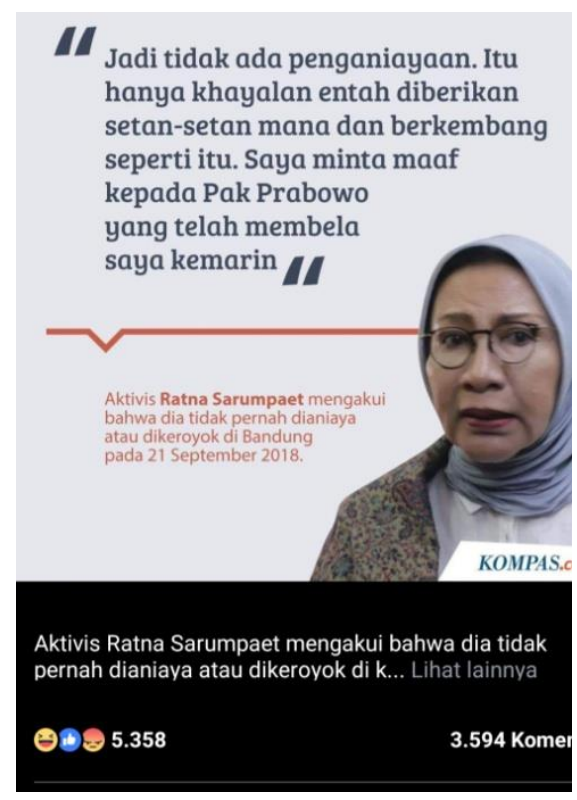

Figure 2. Meme from Facebook published by male politician in Indonesia.

The meme above denotes that the booming phenomenon in Indonesia related to politics particularly the election of President that will be held in 2019. With regard to this, this meme deals with the spread of hoax news stated by the woman activist supporting the candidate of Indonesian President (Prabowo Subianto), Ratna Sarumpaet. She spreads out the hoax news that she was hit and attacked by a group of people supporting another candidate Indonesian President, Jokowi Widodo. Her motive of spreading out the hoax news is to blame the opponent of candidate Indonesian President and to get a positive sympathy from Indonesian people so that they will elect Prabowo to be an Indonesian President. 
Unfortunately, the hoax news has been clearly accessed by the Indonesian people. As a result, she was prisoned due to her hoax news. In accordance with the hoax news made by her, one of Indonesian people makes meme containing hate speech. It can be seen from the content of meme "So, there is no any violence. It is just an imagination from setan-setan (devil) outside. I apologize to Mr. Prabowo for my mistake". The words 'setan-setan' indicates the verbal violence referring to devil.

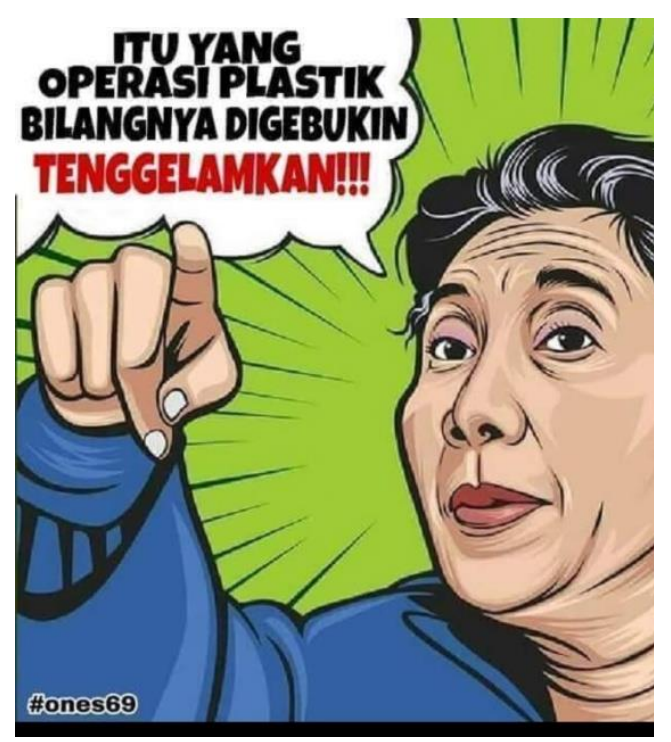

Figure 3. Meme from Instagram published by male politician in Indonesia.

In order to respond the hoax news spread out by Ratna Sarumpaet, one of the Indonesian people makes meme containing hate speech through the words "Tenggelamkan (sink)". The word "tenggelamkan" has the same meaning of being killed.

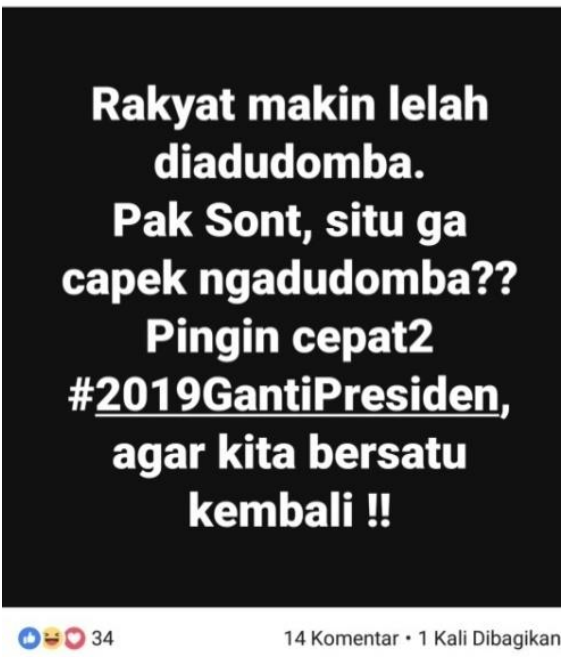

Figure 4. Hate speech captured in Facebook written by a man

Indonesian 2019 election has an emblematic problem. In fact, there is a political polarization between the two-candidate Indonesian Presidents (Joko Widodo and Prabowo Subianto) showed by the conflicts between the Parties of the two candidates. In addition, social media becomes the medium to boost the polarized country. Indeed, many people tried to post messages containing offensive and aggressive news through social media such as Facebook and Instagram. The number of cases related to meme containing hate speech in Indonesia is in line with the studies in Turkish media which show that the increased number of headlines and news stories vilifying specific groups on the basis of ethnicity, religion, gender or sexual orientation(Arcan, 2013).

The meme of figure 4, for instance, indicates that some Indonesian people want to their incumbent 
president is not elected. In other words, they hope that the candidate of Indonesian president, Prabowo can be elected. It could be proved by the words "2019 ganti presiden". Another meme related to political issue in President Election is shown below:

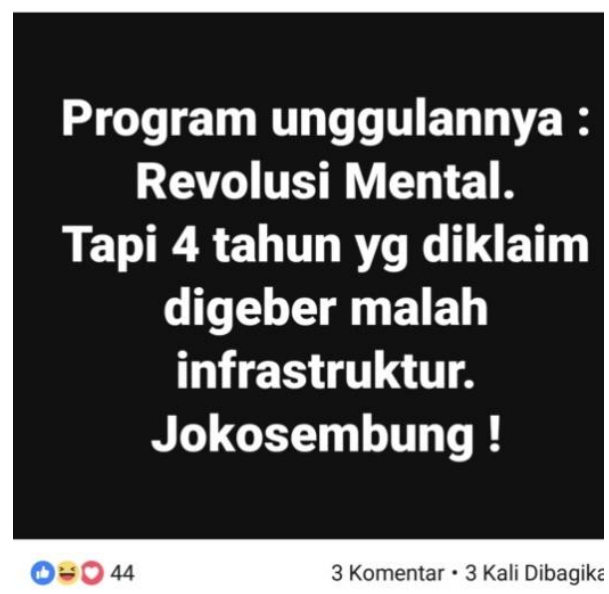

Figure 5. Hate speech captured in Facebook written by a man

The meme in figure 5 contain hate speech and propaganda regarding the work of the previous Indonesian President is not in accordance with his project and program stated some years ago. This is shown by the statements 'the outstanding program is mental revolution, but the focus work for four years is infrastructure'. The meme has an intention to inform people that the previous Indonesian President has not been able to work well for four years. Therefore, the meme recommends people to change the presidents.

Apart from the political issue, another issue on body shaming published on social media is considerably dangerous since it has offensive messages. The following data shows that women have became the victim of body shaming much more than men. This is proved by the percentage of body shaming of women is $94 \%$ while men's percentage of body shaming is 64 $\%$.

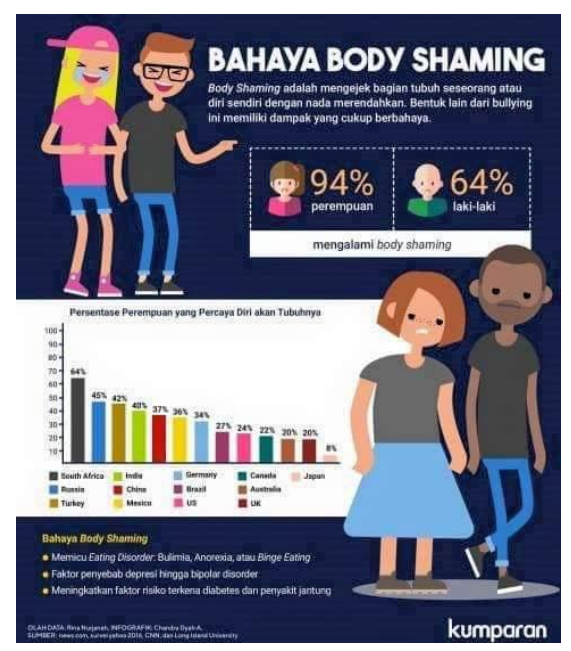

Figure 6. Data of Body Shaming from Internet

The data above show that women may have more preference dealing with physical appearance issues to political ones. This can be seen clearly through the comments stated by women in social media particularly Facebook. Different from women, men tend to have preferences on commenting political issues in social media to physical appearance. Furthermore, they dare to take a risk and power in relation with political issues.

\section{Understanding the Content of Writings} and Memes from Gender and Discourse Perspectives

Recently, social media has played a vital role in delivering news and information. Therefore, people can easily access it. In 
political context, social media is used to convey ideas, programs, vision, mission and so on. Further, it is used to highlight the transparency (Niekerk, 2013). In addition, it is considerably crucial for promoting democracy by contacting different opinions and defying the main discourse by advocating different ideas (Recuero, 2015) . However, social media is not all good. In some aspects, social media have contributed to symbolic violence since it has given a chance for reproducing kinds of discourses particularly violence, for instance. This is in accordance with the statements of Desmond et al advocating that youth violence such as bullying has increasingly spread out in the online space (Desmond et al., 2014). In accordance with the political arena in Indonesia, it seems that there is a disturbing issue of hate discourse indicated by meme and hate speech in social media especially Facebook and Instagram as elaborated previously. A trend tendency in Indonesian politics, for instance, is to represent the Indonesian government and politicians. It has been proved by the following statements containing the hate speech:

"Jadi kita tidak sepakat, atau tidak mau melaksanakan. Karena gini, kita tidak akan bisa melaksanakan kontrol tanpa standar, standar itu sudah ada di republik ini. Kepres mana yang gak ada, SK mana yang gak ada, semuanya ada tapi ketika itu mau dilaksanakan semua karakter dan integritas bangsa ini sangat rapuh" (Https://www.kompasiana.com/mu sniumar/57352f7d5dafbd4f05715c 13/hmi-termukan-musuh-bersamasaut-situmorang, n.d.)

The statement above contains hate speech which refers to certain Islamic
Student Association (HMI) so that it leads to a demonstration, criticism and anger among the alumni of HMI. Considering this, as a public official, he should be careful in choosing words. In this matter, using the term of HMI published in a social media as a reference to corrupt behaviors specifically was emblematic. With regard to the problem, the language user is highly expected to be aware of the norms of language use including interaction rules.

Unlike men that have more tendency to political issues and government organization, women seems have more tendency to talk about physical appearance and gossiping than politics (Wahyuningsih, 2018). It can be seen from the amount of comments dealing with gossiping and physical appearance in social media such as Facebook and Instagram. In addition, women generally are not willing to take a risk and power in accordance with political issue. Interestingly, this finding is in accordance with Holmes in Wardhaugh highlighting that women usually focus on the affective functions of an interaction more often than men do (Wardhaugh, 2006). It is proved by the comments given by women in social media that they have an interest to topics related to daily activities, appearance, and domestic area. In addition, women tend to maintain and increase solidarity while mend tend to communicate in some ways which will focus on the power and status. This is proved by the number of comments stated by men in social media related to political arena in which they tend to give strong arguments towards meme and writings of political issues. Indeed, men are reluctant to give comments on domestic and physical appearance topics. 


\section{Language of Peace on Social Media}

Language has played a main role in conveying message. Therefore, people are supposed to be aware of norms of interaction and consider the role of language of peace. Further, language is the key to the heart of the people and if such a key is lost, the people are lost as well (Damboama, 2010). In conjunction with the political issue, politicians generally use hyperbole language as a means to deliver ideas, messages and programs. In this matter, language is used to enrich a number of jargons in political arena and new meanings of the words. In fact, language is used by them to enrich several jargons in politics and new meanings of the words. It is in line with Lindsay Tanner's statement in Subiakto \& Ida, pointing out that in politics everyone exaggerates about everything all the time (Subiakto \& Ida, 2012). Considering this, it is essential for politicians to be aware of using appropriate language. Besides, they should be aware of pragmatics knowledge which is often used in linguistic especially the interpretation of meaning (O'Keeffe, 2011). Further, sociolinguistic knowledge is crucial to build

\section{RFERENCES}

Arcan, H. E. (2013). Interrupted Social Peace: Hate Speech in Turkish Media. The IAFOR Journal of Media, Communication and Film, 1(1), 43-56.

Carlson, C. (2018). Censoring hate speech in social media content: Understanding the user's perspective. Communication Law Review, 17(1), 24-45.

Damboama, R. D. (2010). Language Education as An instrument of Peace, unity, and Stability in Nigeria. Journal of Assertiveness, 1-5.

Desmond, B., Patton, U., Hong, J. S., the communication in the social context (King \& Wardhaugh, 2006).

\section{CONCLUSION}

To sum up, social media and communication are such two things interrelated to each other. Both of them function to support the social interaction of its users. However, in some aspects, social media has contributed to symbolic violence since it has given a chance for reproducing kinds of discourses particularly violence. The political issue, for instance, has become a disturbing issue of hate discourse indicated by meme and hate speech on social media especially Facebook and Instagram. Considering it, the role of language of peace on social media is badly needed in order to mitigate the potential for conflicts. Therefore, the users of social media both men and women are encouraged to be wise in using social media that can be achieved by using the language of peace to prevent the potential for online conflicts among the society. This can be achieved by having the awareness of pragmatic and sociolinguistic which deal with the use of language, context and interpretation.

Ranney, M., Patel, S., Kelley, C., \& Washington, T. (2014). Social Media as a Vector for Youth Violence: A Review of the Literature. Computers in Human Behavior, 35, 548-553. https://doi.org/10.1016/j.chb.2014.02.0 43

Https://www.kompasiana.com/musniumar/ 57352f7d5dafbd4f05715c13/hmitermukan-musuh-bersama-sautsitumorang. (n.d.). Saut Sitomorang. 
Kennedy, M. A., \& Taylor, M. A. (2010). Online Harassment and Victimization of College Students. Spring, 7(1), 121.

King, R. D., \& Wardhaugh, R. (2006). Introduction to Linguistics. American Speech, $45(3 / 4)$, 285. https://doi.org/10.2307/454846

Niekerk, B. V. A. N. (2013). Social Media and Information Conflict. International Journal of Communication, 7, 1162-1184.

O'Keeffe, et al. (2011). Introducing pragmatics in use. London: Routledge.

Recuero, R. (2015). Social Media and Symbolic Violence. Social Media + Society, 1-3. https://doi.org/10.1177/205630511558 0332

Stephenson, V. L., Wickham, B. M., \& Capezza, N. M. (2018). Psychological Abuse in the Context of Social Media. Violance and Gender, 5(3), 129-134.

Subiakto, H., \& Ida, R. (2012). Political Communication, Media and Democracy. Jakarta: Prenada Media Group.

Wahyuningsih, S. (2018). Men and Women Differences in Using language: A Case Study of Students at STAIN Kudus. Edulite, 3(1), 79-90.

Wardhaugh, R. (2006). An Introduction to Sociolingusitics, Fifth Edition. Oxford: Blackwell Publishing. 